\title{
FREE-MOVEMENT RIGHTS OF THIRD COUNTRY NATIONALS IN THE EU INTERNAL MARKET
}

\author{
JUSTYNA BAZYLIŃSKA-NAGLER*
}

\section{INTRODUCTION}

On 15 and 16 October 1999 the European Council, at its special meeting in Tampere, ${ }^{1}$ confirmed that the legal status of third-country nationals (TCNs) should be similar to that of member states' nationals. In addition, a person residing legally in a member state for a determined time and holding a long-term residence permit should be granted in that member state a set of uniform rights which are as near as possible to those enjoyed by the EU citizens ${ }^{2}$. Integration of third-country nationals who may be: long term residents, EU citizens' family members, students, researchers, highly qualified employees, or even seasonal workers in member states, is crucial for economic and social cohesion. Promotion of these values is a fundamental objective of the EU stated in the Treaty ${ }^{3}$. In order to constitute a genuine instrument for the TCNs integration into the society where they live, they should enjoy equality of treatment with EU citizens in a variety of economic and social matters. ${ }^{4}$

Similarly, the European Parliament and Council stated that all TCNs legally residing and working in the EU should enjoy at least basic equal treatment rights as the nationals of their respective host member state, regardless of their purpose of, or basis for, admission. ${ }^{5}$ The right to equal treatment should be granted not only to TCNs allowed into the internal market to work but also to those who entered for other purposes having access to the labour market under EU or national law, e.g.: family members of a third-

DOI: $10.1515 /$ wrlae-2018-0022

* PhD, Assistant professor, Department of International and European Law, Faculty of Law, Administration and Economics, Wroclaw University; Email: justyna.bazylinskanagler@uwr.edu.pl; ORCID: https://orcid.org/0000-0002-0190-7566.

${ }^{1}$ European Council, Tampere Presidency Conclusions, 15-16.10.1999, no 21.

${ }^{2}$ Council Directive (EC) 2003/109 concerning the status of third-country nationals who are long-term residents [2004] OJ L 016/44, preamble, 2 (LTR Directive).

${ }^{3}$ Treaty on the Functioning of the European Union [2012] OJ C 326/01 (Treaty or TFEU).

${ }^{4}$ LTR Directive, preamble, 12.

${ }^{5}$ Directive (EU) 2011/98 on a single application procedure for a single permit for thirdcountry nationals to reside and work in the territory of a Member State and on a common set of rights for third-country workers legally residing in a Member State [1998] OJ L 343/1, preamble, 19 (Single Application Procedure Directive). 
country worker in line with the Family Reunification Directive, ${ }^{6}$ students under the Students' Directive, ${ }^{7}$ researchers who apply mobility provisions of the Researchers' Directive ${ }^{8}$ or highly-qualified migrants in line with the EU Blue-Card Directive. ${ }^{9}$

Through this work I would like to share some doubts and questions over crucial points of the architecture of the EU system of protection of fundamental rights applied to TCNs, which is uniquely complex. The web of Charter $^{10}$ and European Human Rights Convention ${ }^{11}$ articles is closely interwoven with general principles of EU law and Treaty provisions, as well as with rights enshrined in EU legislation and international association agreements. The importance of general principles of EU law, in particular the principle of effectiveness and non-discrimination pursuant to art 10 TFEU and art 21 of the Charter is crucial because there are no rights of TCNs under the EU primary law. It is also worth remembering that the area of migration policies previously used to be of an intergovernmental nature.

Non-discrimination and equal treatment are important for immigrant's integration. Firstly, discrimination, i.e. undue differential treatment, against certain distinguishable groups in a society points towards prompt social hierarchies. Those who are discriminated against are implicitly seen as being of a lesser value as outsiders who are not worthy of better treatment. Better protection from discrimination has the potential to make these social hierarchies less visible and less perceptible for immigrants which should have positive effects on the prospects of integration. Secondly, integration depends on the economic and social development of immigrants in the receiving society. Accordingly, opportunities for development have to be present to enable integration. These opportunities should be created by legal statuses of TCNs that enable participation and have to be protected by antidiscrimination policies. Therefore, TCNs integration depends on rights to participate which should be accompanied by effective anti-discrimination regulation. ${ }^{12}$

\footnotetext{
${ }^{6}$ Council Directive (EC) 2003/86 on the right to family reunification [2003] OJ L 251/12 (Family Reunification Directive).

${ }^{7}$ Council Directive (EC) 2004/114 on the conditions of admission of third-country nationals for the purposes of studies, pupil exchange, unremunerated training or voluntary service [2004] OJ L 375/12 (Students' Directive).

${ }^{8}$ Council Directive (EC) $2005 / 71$ on a specific procedure for admitting third-country nationals for the purposes of scientific research [2005] OJ L 289/15 (Researchers' Directive).

${ }^{9}$ Directive (EC) 2009/50 on the conditions of entry and residence of non-EU nationals for the purposes of highly qualified employment [2009] OJ L 155/17 (EU Blue-Card Directive).

${ }^{10}$ Charter of Fundamental Rights of the Union [2012] OJ C 326/02 (Charter).

${ }^{11}$ Convention for the Protection of Human Rights and Fundamental Freedoms as amended by Protocols No 11 and No 14 [1950] European Treaty Series No 5.

12 Justice and Home Affairs Council Conclusions, Common Basic Principles of Immigrant Integration Policy in the European Union 15; Moritz Jesse, 'Missing in action: Effective protection for third-country nationals from discrimination under Community Law' in Elspeth Guild, Kees Groenendijk, Sergio Carrera (eds), Iliberal liberal States: immigration, citizenship and integration in the EU (Farnham: Ashgate 2009) 187.
} 


\section{DIFFERENT Legal STATUSES OF THIRD COUNTRY NATIONALS IN THE INTERNAL MARKET}

Since there is no horizontal EU legislation concerning the rights of third-country nationals, their legal positions vary, depending on their nationality and the legislation of their host member state. The European Parliament and Council have attempted to lay down a set of rights in specific fields where equal treatment between EU citizens and TCNs who are not yet long-term residents should be provided. This would contribute to further developing a coherent immigration policy, narrowing the rights gap between EU citizens and TCNs legally working within the internal market. Such provisions help to establish a minimum level playing field within the EU, to acknowledge that TCNs contribute to the EU economy. These rights also serve as a safeguard to reduce unfair competition between a member state's own nationals and TCNs resulting from the possible exploitation of the latter. Beginning from the Ruiz Zambrano ${ }^{13}$ case that became a particularly prominent example of how the reinforcement of citizens' rights often involves a parallel empowerment of the legal position of TCNs, it has been clear that an unstable border between immigration and citizenship situations makes it desirable to have a legal content as similar as possible.

To begin with Treaty provisions - art 79 (4) TFEU sufficiently shows that migration policy always needs accompanying integration policy ${ }^{14}$ - 'The European Parliament and the Council, acting in accordance with the ordinary legislative procedure, may establish measures to provide incentives and support for the action of member states with a view to promoting the integration of third-country nationals residing legally in their territories, excluding any harmonisation of the laws and regulations of the member states'. Article 79 (1) of the Treaty explicitly lays down the competence of the Union to adopt measures regulating a common immigration policy (...) and further - art 79 (2) 'for the purposes of paragraph 1, the European Parliament and the Council, acting in accordance with the ordinary legislative procedure, shall adopt measures in the following areas: (a) the conditions of entry and residence (...) (b) the definition of the rights of third-country nationals residing legally in a Member State, including the conditions governing freedom of movement and of residence in other Member States'. ${ }^{15}$ All four Directives - on long-term residents, students, researchers and highlyqualified migrants contain mobility provisions, allowing TCNs falling within the scope of the directives to move and reside in a second member state if certain conditions are fulfilled.

\footnotetext{
${ }^{13}$ Case C-34/09 Ruiz, Zambrano [2011] ECR I-01177; C- 356/11 O. and S [2012].

${ }^{14}$ Rudolf Geiger, Daniel-Erasmus Khan, Markus Kotzur, European Union Treaties, Treaty on European Union, Treaty on the Function of the European Union, A Commentary (C.H.BECK, Hart 2015) 434.

${ }^{15}$ Article 79 (2) TFEU is not directly effective, however the CJEU recognized direct effect of: arts: 4,13, 14,15 of the Family Reunification Directive, arts: 15, 16 of Directive (EC) 2008/115 on common standards and procedures in Member States for returning illegally staying third-country nationals (C-61/11 El Dridi [2011] ECR I-03015); most of the provisions of LTR Directive are directly effective.
} 


\section{Long-term residents}

Besides measures regarding admission conditions and procedures, EU law at present covers the status of TCNs included within the scope of application of the immigration directives. Particularly, the LTR Directive and the other legal migration directives undertake a task to regulate the most general and basic elements of the status of individuals regardless their intraEU mobility or functional connection to the internal market. Long-term residents enjoy a more privileged status in comparison with other TCNs and hold a specific type of residence permit - the 'long-term resident EU permit'. Therefore, for instance, they are not covered by the Single Application Procedure Directive for a single permit. ${ }^{16}$ Third country nationals residing legally and for a continuous five-year period in a member state may be granted a long term resident status immediately if they submit the relevant application. ${ }^{17}$ To acquire a long-term resident status TCNs should prove that they have, for themselves and for their family members: firstly, stable and regular finances sufficient to maintain their family, without recourse to the social security of the host member state. Member states evaluate these financial resources reconsidering their nature and regularity. They may also take into account the level of minimum wages and pensions prior to the application for long-term resident status. Secondly, sickness insurance in respect of all risks normally covered for nationals in the host member state. ${ }^{18}$ Furthermore, hosting member states may require TCNs to comply with so called 'integration conditions', in line with their national laws.

Integration requirements have significantly affected TCNs' legal statuses; therefore they have been a frequent subject of ECJ ${ }^{19}$ case law. ${ }^{20}$ The corner-stone for EU citizens' integration rights are often subjected to formal integration conditions for TCNs. The case law of the CJEU touching the issue of integration could successfully be applied for TCNs. For instance, the decision in the Forster $^{21}$ case created a strong assumption of integration after five years of legal residence. The Court set out the conditions governing the compatibility of national rules on the award of maintenance grants to students who were nationals of other member states with the principle of the free movement of persons. A German student - Ms Förster, settled in the Netherlands in 2000 to undertake a number of courses there. During her studies, she also had various kinds of paid employment, which entitled her to obtain a maintenance grant from the IB-Groep. However, in the course of a check, the IB-Groep established that for some time in 2003, she was not in paid employment. For this reason the decision relating to the maintenance grant awarded for this period had been annulled with request for the repayment of the excess amounts. Ms Förster brought an action against that decision but was unsuccessful, not only because she did not have

\footnotetext{
${ }^{16}$ Single Application Procedure Directive, preamble, 8.

${ }^{17}$ LTR Directive, art 4.

${ }^{18}$ LTR Directive, art 5.

${ }^{19}$ European Court of Justice (ECJ) after the Lisbon Treaty: The Court of Justice of the European Union (CJEU).

${ }^{20}$ Moritz Jesse, 'The value of "integration" in European law: the implications of the "Förster" case on legal assessment of integration conditions for third-country nationals' (2011) 17 (2) EurLJ 172.

${ }^{21}$ Case C-158/07, Förster v Hoofddirectie van de Informatie Beheer Groep [2008] ECR I8507.
} 
any real and genuine employment in the period in question, but also because she could not be regarded as being 'sufficiently integrated' in the Netherlands and was not therefore entitled to the maintenance grant. The Court decided that a national of one member state, who goes to another member state to follow a training course there, is covered by arts $18 \mathrm{EC}$ - on the free movement right of EU citizens and $12 \mathrm{EC}$ - on the prohibition of discrimination on grounds of nationality. In principle, these provisions require the host state to award to the nationals of other member states the same maintenance grants as those awarded to its own nationals. The 'Forster assumption of integration' cannot be disregarded easily by national courts assessing the legality of integration conditions for TCNs put in place in addition to residence requirements taking into account their obligation to keep coherence with EU law.

The first three judgements interpreting the long-term residents directive created a subsidiary form of EU citizenship for third country nationals. ${ }^{22}$ These judgements: Kamberaj ${ }^{23}$, Commission v. Netherlands ${ }^{24}$, Mangat Singh ${ }^{25}$ on the LTR Directive have clearly laid out the direction for the Court's future interpretation of this legislation. The Court has referred repeatedly to the directive's stated objective of the integration of TCNs, but also to the objective of equal treatment and even the development of the internal market and the free movement of persons. The Court has insisted on a uniform interpretation of the definition of 'formally limited' permits and 'core benefits', and insisted on a strict interpretation of the derogation relating to equal treatment. The Kamberaj case dealt with TCNs' statuses and their implications for national social security systems. Servet Kamberaj, from Albania, resided legally for an indefinite period in Italy, where he was denied certain housing benefits. He claimed that this resulted in discriminatory treatment between him and EU citizens; because the budget of those housing benefits was divided into two categories - for the EU citizens and for TCNs, only the finances for the second category were spent. The Court decided that the concept of social security and social protection encompasses housing benefits and that the principle of equal treatment cannot be limited to 'core benefits' of the social security system in such a way that it would exclude housing benefits. In Commission v. Netherlands case the Court declared that excessive and disproportionate administrative charges for applications for residence permits for long-term residents and their family members created an obstacle to the exercise of their rights. The Singh judgement concerned the interpretation of art 3 (2)(e) of the LTR Dir that excludes from the scope of

\footnotetext{
${ }^{22}$ Steve Peers, 'The Court of Justice lays the foundations for the long-term residents directive: Kamberaj, Commission v. Netherlands, Mangat Singh. Case C-571/10, Servet Kamberaj v. Istituto per l'Edilizia sociale della Provincia autonoma di Bolzano (IPES) and Others, Judgment of the Court (Grand Chamber) of 24 April 2012, Case C-508/10, Commission v. Netherlands, Judgment of the Court of 26 April 2012; Case C-502/10, Staatssecretaris van Justitie v. Mangat Singh, Judgment of the Court of 18 October 2012' (2013) 50 (2) CML Rev 529-552.

${ }^{23}$ Case C-571/10, Servet Kamberaj v. Istituto per l'Edilizia sociale della Provincia autonoma di Bolzano (IPES) and Others [2012].

${ }^{24}$ Case C-508/10, European Commission v Kingdom of the Netherlands [2012].

${ }^{25}$ Case C-502/10, Staatssecretaris van Justitie v Mangat Singh [2012].
} 
the directive the TCNs residing only temporarily, such as au pair or seasonal worker, or as workers posted by a service provider to deliver services crossborderly, or as cross-border providers of services or in cases where their residence permits have been formally limited. For instance, Mr. Singh, an Indian citizen had arrived in the Netherlands in 2001 and had been granted a residence permit for the activity of 'spiritual leader'. Under national law, this was a fixed-period permit which fell within the exclusion in the Directive for residence permits which were formally limited, so Mr. Singh's application for LTR permit in 2007 was denied. The Court decided that the formal limitation attached to Mr. Singh's permit does not prevent the long term residence of the TCN in the host member state. The ECJ's conclusions from the cases cited above also suggest that the list of conditions to obtaining longterm resident status is exhaustive; however the Court did not expressly confirm this interpretation. ${ }^{26}$ First of all, the Court has confirmed that attaining long-term resident status is dependent upon applying for it. ${ }^{27}$ There is an obligation to grant long-term resident status if the relevant conditions are met. Third country nationals apply for this status despite the high fees, but obviously - more TCNs would apply if the fees were lower.

For the reasons stated above, we may say that free movement is a precondition for the integration of third country nationals in the EU. ${ }^{28}$ The relevance of the principle of free movement of persons to the components of European citizenship status has undoubtedly been recognized and is a fundamental right in the EU Charter. ${ }^{29}$ Whereas EU citizens benefit from extensive free-movement rights, the same does not hold true for TCNs. The position of TCNs differs significantly from that of EU citizens, as they do not enjoy a right to free movement on the basis of primary EU law. Therefore, this article focuses on secondary law free-movement rights granted to certain categories of TCNs. For the sake of conciseness, only 'the mobility provisions' and their limitations contained in the relevant Directives - on long-term residents, researchers, students, and highly-qualified migrants have been commented on below.

Free-movement rights for TCNs were introduced for the first time with the adoption of the LTR Dir in Nov. 2003. Several provisions of this directive left a huge margin of discretion for member states - possible limitations are set out in arts 14 (3) and 14 (4). Article 14 (3) provides for exceptions to free movement on the basis of the labour market situation of the member state concerned. Member states are allowed to apply their own procedures for filling vacancies, as well as to give preference to Union citizens and resident unemployed TCNs. Moreover, in line with art 14 (4) maximum limits of long-term residents may be admitted to stay in a second member state, if such provisions were already applicable in the national law of the member state concerned when adopting this directive. Instead of quota

\footnotetext{
${ }^{26}$ Kamberaj, para 66 - 67; Commission v Netherlands, para 67; C-40/11-Yoshikazu Iida v Stadt Ulm [2012] para $36-48$.

${ }^{27}$ Commission v Netherlands, para 67; Iida para 47.

${ }^{28}$ Sara Iglesias Sánchez, 'Free movement as a precondition for integration of third-country nationals in the EU' in Elspeth Guild, Kees Groenendijk, Sergio Carrera (eds) (n 12) 187 202.

${ }^{29}$ Charter, art 45.
} 
regimes ${ }^{30}$ member states who are barred from introducing annual quotas due to the stand-still clause contained in art 14 apply national labour market tests. For instance, in Germany the economic activity of long-term residents is only permitted in cases where the Federal Employment Agency has granted approval. An exception to the requirement of approval from the Federal Employment Agency is only made for highly-qualified workers, researchers and self-employed long-term residents. ${ }^{31}$ Nationally-determined requirements of host member state make TCNs integration difficult, what's more the conditions for residence in a second member state make TCN's free circulation within the internal market almost impossible. According to art 15 of the directive 2003/109 the conditions for residence in a second member state are similar to the rules for attaining long-term residence status in the first one. Member states generally subject long-term residents from another member state to the same conditions as for the initial entry with the exception of the requirement to apply for a residence permit from abroad. Additionally, art 15 (3) makes it possible for member states to impose integration requirements on TCNs exercising their free-movement rights only if the person concerned has not already met integration conditions when acquiring long-term resident status in the first member state. The possibility of subjecting long-term residents from another member state to integration requirements has been applied in numerous member states - in the Netherlands, Austria, Germany, and France. Article 21 (1) of the LTR Directive allows member states to restrict labour market access for a period of up to 12 months for certain economic activities. For instance, in the Netherlands during their first 12 months of residence, long term residents from other member states are subjected to a labour market test and have to acquire a work permit from the Centre for Work and Income (Centrum voor Werk an Inkomen). In Germany, even in cases where the Federal Employment Agency has given its approval, the right to employment may be restricted to a certain occupational activity, specific plants or regions for a period of up to 12 months. ${ }^{32}$ It is not only the employment rights of long-term residents moving to another member state that are limited - they are also subject to far less beneficial family reunification rules than EU citizens. According to art 16 of the LTR Directive the spouse and minor children of a long-term resident exercising his right to move to another member state must be allowed to accompany him or her, provided that the family was already constituted in the first member state. For other categories of family members who were already part of the family unit in the first member state, admission depends on the exercise of discretion by the second member state. In cases where the family was not already constituted in the first member state art 16

\footnotetext{
${ }^{30}$ For instance in Austria the number of long-term residents from other Member States who are admitted for the purposes of settlement is fixed on an annual basis - Sec 13(2) No.2 Settlement and Residence Act (Niederlassungs - und Aufenthaltsgesetz), Federal Law Gazette 100/2005 (NAG); Anja Wiesbrock, 'Free movement of third-country nationals in the European Union: the illusion of inclusion' (2010) 35(4) EL Rev 463.

${ }^{31}$ Sec 38a (3) jo.18(2),10,20 and 21 Residence Act (Aufenthaltsgesetz), Jan 1, 2005; Wiesbrock (n 30) 463.

32 On the implementation of four directives on legal migration of TCNs in Member States Anja Wiesbrock, Legal migration to the European Union (Leiden: M. Nijhoff 2010) 303496.
} 
(5) of the Family Reunification Directive applies. Therefore, the right of longterm resident TCN to bring their family members to a second member state when exercising free-movement rights derived from Directive 2003/86 differs significantly from the family reunification rights of moving EU citizens.

\section{Students, researchers and highly qualified employees}

One of the few advantages of strongly criticized Students' Directive is the introduction of a mobility provision for students from third countries. Article 8 of the Directive grants immigrants who had already been admitted as students in one of the member states the right to reside in another member state for the continuation of their studies. This possibility, however opened up to third-country national students to move to a second member state is subject to significant limitations - arts 6 and 7 of the Directive must be fulfilled. This means that students moving to a second member state are required to demonstrate that they have been admitted to an establishment of higher education and that they have sufficient resources to cover study fees, subsistence and return travel costs. Additionally, the applying student has to study in the first member state for at least 2 years or has to participate in an exchange programme, unless the study period abroad constitutes an obligatory part of a chosen study programme. Therefore, the situation of TCNs is not comparable to the EU students whose stay in another member state for the purpose of studies is facilitated and even encouraged. ${ }^{33}$

The limitations of the mobility provisions in the Researchers' Directive are set out in the art 13, as regards the right to move to another member state for a period up to 3 months - arts 13 (1), 13 (2), 13 (4) allow member states to demand visa or residence permit in accordance with national law from visiting researchers making use of the possibility of intracommunity mobility. Third country researchers with a valid travel document and a residence permit issued by one of the Schengen states will, in any case, be able to enter and reside in another member state for up to 3 months if the conditions from art 21 of the Schengen convention are met. For a period of more than 3 months the conclusion of a new hosting agreement in the second member state may be required. In any event the second member state may refuse to admit researchers from other member states who do not have sufficient resources to maintain themselves or who constitute a threat to public policy, security or health. As regards the right to family reunification, Directive $2005 / 71$ is characterized by the lack of any provision granting researchers the right to be joined by their family members from abroad. Concerning movement to a second member state, rec 19 of the preamble to the directive merely encourages member states to allow family members to join the researcher in another member state under the national law conditions. The relevance of Family Reunification Directive in this respect is omitted with an exclusive reference to national law. ${ }^{34}$ Blue Card holders, after 18 months of their legal residence, may take up employment for highly-qualified workers in a second member state ${ }^{35}$. This requires, however, the submission

\footnotetext{
${ }^{33}$ Steve Peers, 'Key legislative developments on migration' (2005) 7 European Journal of Migration and Law 103.

${ }^{34}$ Wiesbrock (n 30) 278- 284.

${ }^{35}$ EU Blue-Card directive, art 18.
} 
of an application for a Blue Card within one month after arrival to that second member state or when the Blue Card holder is still residing in the first member state. It is worth considering that there is no free movement of Blue Card holders within the internal market. In order to be granted Blue Card in a second member state, the same requirements as those for entry have to be met. It is not clear whether member states are obliged to admit highly-skilled migrants from other member states even if all conditions are fulfilled. Member states still remain free to apply quotas when considering the admission of highly-skilled migrants from other member states.

To conclude, by subjecting TCNs to numerous, nationally-determined requirements the essence of the mobility provisions is undermined, especially the idea of free-circulation of labour between the member states had been demolished. On account of all the relevant provisions cited above it seems to be clear that entry to a second member state has become at least as difficult for TCNs as their first admission.

\section{Family members}

The family reunification right is necessary for making family life possible. It helps to create sociocultural stability facilitating TCNs' integration in member states ${ }^{36}$. Material conditions for exercising the right to family reunification should be compliant with the family protection principle and such goals as establishment or preservation of family life, for that reason they should be determined on the basis of common criteria. Family reunification should apply in any case to members of the nuclear family, i.e. the spouse and the minor children. The CJEU case law concerning family reunification rights is especially complex, because the first thing to decide is which directive is relevant in a particular case - the Family Reunification Directive 2003/86 - solely applied to TCNs and their family members or Directive 2004/38/EC on the right of citizens of the Union and their family members, who may also be TCNs $(!)^{37}$. Moreover, the levels of protection of the same right under these two legal instruments differ significantly.

In the Chakroun ${ }^{38}$ judgement, the Court strengthened the right to family reunification and family formation of TCNs which stems from the right to respect for private and family life enshrined in art 7 of the EU Charter of Fundamental Rights. The Court clearly established family reunification as a right of a legally residing third-country national in the EU. The case was brought before the ECJ by Dutch Raad van State in the course of proceedings involving a citizen of Morocco, Rhimou Chakroun, who wished to obtain a residence permit to join her husband, a long-term resident of Netherlands. In 2006, Ms Chakroun applied for a Dutch residence permit in order to live with her husband, her application was denied, because her husband's unemployment benefits were below the required minimum income. Rhimou Chakroun appealed the decisions of the Minister and of the Hague District

\footnotetext{
${ }^{36}$ Family Reunification Directive, preamble, 4.

${ }^{37}$ Directive 2004/38/EC on the right of citizens of the Union and their family members to move and reside freely within the territory of the Member States amending Regulation (EEC) No 1612/68 and repealing Directives 64/221/EEC, 68/360/EEC, 72/194/EEC, 73/148/EEC, 75/34/EEC, 75/35/EEC, 90/364/EEC, 90/365/EEC and 93/96/EEC [2004] OJ L 158/77 (EU Citizens' Directive).

${ }^{38}$ Case C-578/08 Rhimou Chakroun v Minister van Buitenlandse Zaken [2010] ECR I-01839.
} 
Court. She challenged the compatibility of the Dutch law on the minimum wage and minimum holiday allowance with the Family Reunification Directive, as well as the distinction drawn between family formation and reunification, i.e. whether a family relationship arose before or after the entry of the resident, under Dutch law. The CJEU has emphasized the existence of TCNs' right to family reunification and formation, and restricted the possibilities for derogation from that right. ${ }^{39}$ The Family Reunification Directive does not make a distinction between whether a family relationship arose before or after the entry of the resident into the member state. ${ }^{40}$ The message that the Court put across the member states was that they are considerably limited in their possibilities to restrict entry and residence rights of TCNs' family members falling within the scope of the Directive, even if certain provisions thereof provide for the imposition of additional requirements in accordance with national law.

The Grand Chamber decision of 2007 in case C-1/05 Yunying Jia v. Migrationsverket clarified what law - the EU or national, governs the first entrance to the EU territory by a TCN who is a family member of an EU citizen who has migrated to a host member state. Ms Jia, a Chinese national carrying a tourist visa, joined her son, also a Chinese living with his German wife in Sweden. She applied to the Swedish authorities for a residence permit on the grounds of relationship with an EU national and of financial dependence on her son and daughter-in-law. The application was rejected because of an inadequate evidence of financial dependence. An appeal against this rejection was taken to the Utlänningsnämnden (Aliens Appeals Board), which raised questions about the interpretation of the conditions under which TCNs - members of the family of an EU national are entitled to a residence permit in the EU, considering in particular the prior condition of being legally resident in a member state and the existence of financial dependence for the purposes of relevant Directive. The Court recalled the relevance of a previous judgment in the Akrich case and decided that the grant of a residence permit in the present case must not be subject to the prior condition that the national of the third country has legally resided in another Member State. ${ }^{41}$ The Eind case ${ }^{42}$ concerned a Dutch national who went to the UK in 2000, where he was employed. He was then joined by his daughter Rachel, born in 1989, who arrived direct from Surinam. Both Mr and Miss Eind had a right to reside in the United Kingdom in line with Regulation No 1612/68. In October 2001, the father and his daughter entered the Netherlands, where Mr Eind did not carry out any economic activity due to his health problems. Miss Eind registered with the Amsterdam police and applied for a residence permit, her application was refused. In its Grand Chamber decision of 11

\footnotetext{
39 Anja Wiesbrock, 'The right to family reunification of third-country nationals under EU law: Decision of 4 March 2010, Case C-578/08, Rhimou Chakroun v. Minister van Buitenlandse Zaken' (2010) 6(3) European Constitutional Law Review 462-480.

${ }^{40}$ Rhimou Chakroun (n 38) 67.

${ }^{41}$ Ben Olivier, Jan Herman Reestman, 'European citizens' third country family members and Community law: Court of Justice of the European Communities. No legal residence requirements for the admission of family members with a third-country nationality of migrated Union citizens. Grand Chamber decision of 9 January 2007, case C-1/05, "Yunying Jia v. Migrationsverket"' (2007) 3(3) European Constitutional Law Review 463-475.

${ }^{42}$ Case C-291/05, Minister voor Vreemdelingenzaken en Integratie v R. N. G. Eind [2007] ECR I-10719.
} 
December 2007, the Court affirmed a right of residence for a family member who was a TCN upon the return of a Union citizen to the home member state, even when the Union citizen no longer carried on any effective and genuine economic activities. ${ }^{43}$

In cases decided in $2012-O, S \& L^{44}$, the crucial preliminary question was whether a TCN step-parent could derive a right of residence from his step-child who was an EU citizen. Two women: a Ghanaian and an Algerian had moved to Finland, to marry Finnish men and each gave birth to a child of Finnish nationality. After the marriages broke down, the mothers received custody of their children. Next, the women remarried to TCN men and had a second child of the mother's nationality. Their TCN step-fathers applied for residence permits that were refused on grounds of lack of resources to maintain. The Court stressed that member states must apply the provisions of the family reunification directive in the light of the arts 7 and 24(2) and (3) of the Charter, making 'a balanced and reasonable assessment of all the interests in play, taking particular account of the interests of the children concerned" and "avoiding any undermining of the objective and the effectiveness of that directive. ${ }^{45}$ For this purpose the Court stressed the role of the national judge in the EU law application - they must balance competing interests always upholding Charter rights when applying both national and EU law. If we compare the results of $O, S$ and $L$ case with the findings of the Court, for instance in the landmark Dereci ${ }^{46}$ case from 2011, it becomes clear that the protection of fundamental rights of TCNs under the scope of the family reunification directive may even surmount that of EU citizens under the 2004/38/EC directive (!). However, to be meticulous in these matters, we should not overlook an earlier and very 'citizen friendly' case - Metock and Other ${ }^{47}$ decided in 2008, when the Court reversing the Akrich case ${ }^{48}$, rejected a narrow interpretation of the rights of family members of EU citizens supporting the argument that such an interpretation would be paradoxical since it would impose less favourable conditions to Union citizens than to TCNs under Directive 2003/86. ${ }^{49}$ The Court underlined that EU citizens have the right to be accompanied by their family members as defined in Directive 2004/38, irrespective of where and when the family relationship was established.

\footnotetext{
${ }^{43}$ Jeremy B Bierbach, 'European Citizens' Third-Country Family Members and Community Law: Grand Chamber decision of 11 December 2007, Case C-291/05, Minister voor Vreemdelingenzaken en Integratie v. R.N.G. Eind The return of the member state national and the destiny of the European citizen'(2008) 4(2) European Constitutional Law Review 344-362.

${ }^{44}$ Cases C-356-367/11 [2012].

${ }^{45}$ ibid [78].

${ }^{46}$ Case C-256/11, Dereci and others [2011] ECR I-11315.

${ }^{47}$ C-127/08 [2008] ECR I-6241.

${ }^{48} \mathrm{C}-109 / 01$ [2003] ECR I-9607.

${ }^{49}$ Metock (n 47) [69].
} 


\section{ThIRD COUNTRY NATIONALS' Rights IN THE ChaRTER OF FUNDAMENTAL RIGHTS OF THE EU}

Freedom, security and justice, non-discrimination and Union citizenship are areas where fundamental rights are especially relevant, according to the European Commission, the principle that the member states must uphold fundamental rights when implementing EU law is particularly important there.$^{50}$ Among those relevant for regular migrants rights are all the rights listed in the preambles to the migration directives discussed in this article, in particular: respect for private and family life, ${ }^{51}$ freedom to choose an occupation and right to engage in work, ${ }^{52}$ the right to property, ${ }^{53}$ workers' right to information and consultation within the undertaking, ${ }^{54}$ the right of collective bargaining and action, ${ }^{55}$ fair and just working conditions, ${ }^{56}$ family and professional life ${ }^{57}$ - all applied in accordance with art 6 TEU. ${ }^{58}$

The Charter of Fundamental Rights of the EU is only applicable within the scope of application of the Treaty ${ }^{59}$ - the notion of 'scope of application of the Treaty' is not defined there, and may expand or contract depending on whatever approach the CJEU takes in its various decisions. However, the majority of the Court decisions confirm that national measures related to admission conditions and procedures of TCNs' family members, long- term residents, students, researchers and the EU Blue-card holders are now likely to fall within the category of measures implementing EU law ${ }^{60}$ and therefore are covered by the Charter. Even though the area of asylum and immigration law is burdened with many derogation clauses and references to national law, according to K. Lenaerts, all these situations can be considered as circumstances in which a member state adopts measures to comply with obligations that arise from EU law. ${ }^{61}$

Nonetheless, the EU Charter of Fundamental Rights makes a clear distinction between EU citizens' and third country nationals' rights. To make an example, art 45 (2) of the Charter states that legally residing TCNs may be granted free-movement rights in accordance with the Treaty provisions. To

\footnotetext{
${ }^{50}$ European Commission Communication, Strategy for the effective implementation of the Charter of Fundamental Rights by the European Union, COM (2010) 573/4.

${ }^{51}$ Charter, art 7; Case 413/99, Baumbast und $R v$ Secretary of the State for the Home Department [2002] ECR I-7091; Case C-109/01, Akrich [2003] ECR I-9607; Case C-157/03, Commission v Spain [2005] ECR I -2911.

${ }^{52}$ Charter, art $15(3)$.

53 ibid art 17.

54 ibid art 27.

55 ibid art 28.

56 ibid art 31(1).

57 ibid art $33(2)$

${ }^{58}$ Directive 2014/36/EU on the conditions of entry and stay of third-country nationals for the purpose of employment as seasonal workers [2014] OJ L 94/375, preamble, 52.

${ }^{59}$ Charter, arts 6, 51.

${ }^{60}$ The notion of measures implementing EU law: Wachauf (5/88) (1989) ECR 2609; Booker Aquaculture (C-20 and 64/00) (2003) ECR I-7411 (measures that serve as implementing acts of EU law); ERT (C-260/89) (1991) ECR I-2925, Runevic-Vardyn (C-391/09) of 12 May 2011, para 52; Tsakokuridis (C-145/09) of 23 Nov. 2010, para 25 (measures that make use of justifications derogating from EU law).

${ }^{61}$ Koen Lenaerts, Ignace Maselis, Kathleen Gutman, 'Jurisdiction of the Court of Justice of the European Union with regard to the Area of Freedom, Security and Justice' in Janek Tomasz Nowak (ed) EU procedural law (OUP 2015) 726-736.
} 
the contrary, EU citizens have the right to move and reside freely within the territory of the member states - solely by virtue of art 45 (1) of the Charter and relevant Treaty provisions. Thus, the Charter clearly reaffirms the distinction between EU citizens and TCNs as regards access to free movement as well as other civic and political rights. ${ }^{62}$

The judgement of the Grand Chamber of 27 June 2006 in case Parliament $v$ Council ${ }^{63}$ was the first one reviewing instruments adopted under Title IV of the EC Treaty; this time the Family Reunification Directive. The so-called immigration directives are of interest in view of the CJEU's human rights protection - by their nature and the fact that instruments in the field of migration and asylum affect the position of individuals. The Court is competent to review whether these measures, as well as national implementing laws are in conformity with the fundamental rights protected in the Charter. Directive 2003/86/EC determines the conditions for the exercise of the right to family reunification by TCNs residing lawfully in the territory of the member states. The Directive allows member states to introduce certain derogations. Parliament applied for annulment of three derogations from that principle as being contrary to fundamental rights, in particular the right to family life and the right to non-discrimination. The Court had regard in particular to: the European Convention on Human Rights, two United Nations conventions: the International Covenant on Civil and Political Rights ${ }^{64}$ and the Convention on the Rights of the Child ${ }^{65}$, the Charter of Fundamental Rights of the European Union, although at that time it was not a legally binding instrument. ${ }^{66}$ The Court pointed out that its review of compliance with fundamental rights also extends to the provisions of a directive permitting member states to apply derogations, since such derogations could require or authorise them to adopt or uphold national laws contrary to these rights. However, the final conclusion was that none of the contested derogation provisions could be regarded as running counter to the rights at issue, either in themselves or in that they expressly or impliedly authorised the member states to act in such a way. The Court therefore endorsed the Commission approach in its supporting Council intervention. Lastly, the Court recalled that implementation of the directive is subject to review by the national courts, before which a decision rejecting an application for family reunification may be challenged, and which may refer questions for a preliminary ruling in accordance with former art 234 of the Treaty.

The questions of applicability of the Charter of Fundamental Rights and the European Convention on Human Rights (ECHR) as regards to the

\footnotetext{
62 Theodora Kostakopoulou, 'Long-term resident third-country nationals in the EU: normative expectations and institutional openings' (2002) 28 Journal of Ethnic and Migration Studies, 443.

${ }^{63}$ C-540/03, [2006] ECR I - 5769.

64 Adopted and opened for signature, ratification and accession by General Assembly resolution 2200A (XXI) of 16 December 1966, entry into force 23 March 1976, in accordance with Article 49.

65 Adopted and opened for signature, ratification and accession by General Assembly resolution 44/25 of 20 November 1989 entry into force 2 September 1990, in accordance with Article 49.

${ }^{66}$ Parliament v Council [35-38].
} 
national laws governing TCNs' rights appeared again in the Iida ${ }^{67}$ case. The Court, in the judgement of 2012, rejected the applicability of the Charter to a TCN family member that sought to assert a residence right as EU family member in the state of origin of the EU citizen, despite the fact that they already moved into another member state. The Court decided that Mr. Yoshikazu Iida, the Japanese parent of a German child residing in Austria with her mother could not invoke a right of residence in his place of dwelling and working; Germany, on the grounds that he was the father of an European citizen, because it would not deprive the daughter of the 'genuine enjoyment of her rights' nor would it impede her from moving freely within the EU. The Court stated that even though the German national rule that regulated the situation had been adopted in implementation of EU law, his situation fell outside Directive 2004/38 and had no other connection with EU law. The rejection of the application of fundamental rights because the Court failed to establish a link to EU law seems to be controversial in this case. ${ }^{68}$

\section{CONCLUSIONS}

The Stockholm Programme and, implementing it' the European Commission's Action Plan, spoke of 'Europe's citizens' rights - not necessarily only Europeans or the EU member states' citizens (!) but including also third country nationals. It was stressed there that due to an increasing demand for labour, well-managed migration can make an important contribution to the Union's economic development and performance in the long term and that integration remains the key element to maximizing the benefits of immigration. ${ }^{69}$

Accordingly, the EU law confers rights on third-country nationals and attempts to approximate them to those of European citizens. Since this approximation until now has extended to social and economic matters, the element of mobility remains central to the recognition of the citizenship-like freedoms of TCNs under the migration directives. The Court of Justice of the EU rulings studied in this work confirmed that TCNs enjoy and benefit from a number of EU citizenship-related freedoms, rights, benefits and general principles which are subject to protection and review at the EU level.

Nevertheless, free-movement provisions in the Council migration directives illustrate the restrictive nature of EU migration law, which continues to be dominated by state discretion rather than focusing on the rights of TCNs. Not surprisingly, especially the parts of the immigration directives concerning intra-EU mobility of TCNs have been among those for which national transposition by EU member states has been most

\footnotetext{
${ }^{67} \mathrm{C}-40 / 11$, [2012] [79-80].

${ }^{68}$ Opinion of AG Trstenjak, Case C-40/11, Yoshikazu Iida v Stadt Ulm, 2012 May 15.

69 Stockholm Programme: An open and secure Europe serving and protecting citizens, Council of the European Union, 5731/10 Brussels, 3 March 2010, p 6.1.5; European Commission Communication on Delivering an Area of Freedom, Security and Justice for Europe's Citizens: Action Plan Implementing the Stockholm Programme, COM (2010) 171, Brussels, 20 April 2010.
} 
unsatisfactory. ${ }^{70}$ The need for improvement of the effectiveness of the EU migration law mobility provisions is urgent. ${ }^{71}$ Consequently, rather than being fully included into the internal market TCNs in the EU continue to be marginalized. On the other hand, the case law concerning family reunification rights of TCNs seems to be very dynamic - the results of the $O, S$ and $L$ case compared with the findings of the Court in Dereci leads to the conclusion that protection of fundamental rights of TCNs under the scope of the family reunification directive, incidentally, may even surmount that of EU citizens under 2004/38 directive.

However, these balancing exercises of the CJEU have not led to creation of general, uniform status of TCNs within the EU concerning their fundamental rights. The main reason for this seems to be a deficit of political will. There is an urgent need to come back to a positive notion of integration. In recent years the concept of integration has been increasingly used in a negative sense, as a restrictive mechanism in the hands of the member states to reduce TCNs access to a secure residence status and fundamental rights. The European Union institutions should revert to the positives of integration, seeing it as a multidimensional process in multicultural societies, characterized by diversity and multiple belongings. This does not preclude the application of publicly organized integration measures as long as participation is not mandatory and integration conditions are not used as a tool of immigration control. ${ }^{72}$

\section{References}

Ball R, The Legitimacy of The European Union through Legal Rationality: Free Movement of Third Country Nationals (Routledge Research in European Union Law 2013)

Barret G, 'Family Matters: European Community Law and Third-Country Family Members' (2003) 40 CML Rev 369-421

Bierbach JB, 'European citizens' third-country family members and Community law: Court of Justice of the European Communities' (2008) 4(2) European Constitutional Law Review 344-362

Boelaert-Suominen S, 'Non-EU nationals and Council directive 2003/109/EC on the status of third-country nationals who are long-term residents: five paces forward and possibly three paces back' 2005 42(4) CML Review 1011-1052

Carrera S, Faure Atger A, Implementation of Directive 2004/38 in the context of EU enlargement : a proliferation of different forms of citizenship? (CEPS 2009)

-- and Parkin J, Protecting and delivering fundamental rights of irregular migrants at local and regional levels in the European Union (Committee of the Regions, CEPS Brussels 2011)

-- and Wiesbrock A, Whose European citizenship in the Stockholm Programme? The enactment of citizenship by third country nationals in the EU (2010) 12(3) European Journal of Migration and Law 337-359

\footnotetext{
${ }^{70}$ Sergio Carrera, Anaïs Faure-Atger A., Implementation of Directive 2004/38 in the context of EU enlargement: a proliferation of different forms of citizenship? (Centre for European Policy Studies (CEPS) 2009).

${ }^{71}$ Wiesbrock, Free movement, (n 30) 455-475.

${ }^{72}$ Wiesbrock A, Legal migration (n 32) 765.
} 
Eisele K, The External Dimension of the EU's Migration Policy Different Legal Positions of Third-Country Nationals in the EU: A Comparative Perspective (Wolf legal Publishers 2014)

Elsuwege P, Kochenov D, 'On the limits of judicial intervention: EU citizenship and family reunification rights' 2011 13(4) European Journal of Migration and Law 443-466

Geiger R, Khan D-E, Kotzur M, European Union Treaties, Treaty on European Union, Treaty on the Function of the European Union, A Commentary (C.H.BECK Hart 2015)

Goldner Lang I, From Association to Accession. How Free is the Free Movement of Persons in the EU (Eleven International Publishing 2011)

Groenendijk K, Guild E, Barzilay R, The Legal Status of Third Country Nationals who are Long-Term Residents in a Member State of the European Union (Centre for Migration Law, University of Nijmegen 2000)

Guild E, Peers S, Tomkin J, The EU citizenship directive: a commentary (OUP 2014)

Hardy J, 'The objective of Directive 2003/86 is to promote the family reunification of third country nationals' (2012) 14(4) European Journal of Migration and Law 439-452

Hedemann-Robinson M, 'An overview of recent legal developments at Community level in relation to third country nationals resident within the European Union, with particular reference to the case law of the European Court of Justice' (2001) 38(3) CML Rev 525-586

Hublet C, 'The scope of article 12 of the Treaty of the European Communities "visà-vis" third-country nationals: evolution at last?' (2009) 15(6) European Law Journal 757774

Jesse M, 'Missing in action: Effective protection for third-country nationals from discrimination under Community Law' in Elspeth Guild, Kees Groenendijk, Sergio Carrera (eds), Iliberal liberal States: immigration, citizenship and integration in the EU (Farnham: Ashgate, 2009)

-- "The value of "integration" in European law: the implications of the "Förster" case on legal assessment of integration conditions for third-country nationals' (2011) 17(2) European Law Journal 172-189

Iglesias Sánchez S, 'Free movement as a precondition for integration of thirdcountry nationals in the EU' in Elspeth Guild, Kees Groenendijk, Sergio Carrera (eds), Iliberal liberal States: immigration, citizenship and integration in the EU (Farnham: Ashgate, 2009)

-- 'Fundamental rights protection for third country nationals and citizens of the Union: principles for enhancing coherence' (2013) 15(2) European Journal of Migration and Law, 137-153

Kostakopoulou T, 'Long-term resident third-country nationals in the EU: normative expectations and institutional openings' (2002) 28 Journal of Ethnic and Migration Studies, 443

Lenaerts K, Maselis I, Gutman K, 'Jurisdiction of the Court of Justice of the European Union with regard to the Area of Freedom, Security and Justice' in Janek Tomasz Nowak (ed), EU procedural law (OUP 2015)

Łazowski A, 'Enhanced Multilateralism and Enhanced Bilateralism: Integration without Membership in the European Union' (2008) 45 CML Rev 1433-1458

Morano-Foadi S, Malena M, Integration For Third-Country Nationals In The European Union. The Equality Challenge (Oxford Brookes University 2012)

Olivier B, Reestman JH, 'European citizens' third country family members and Community law: Court of Justice of the European Communities. No legal residence requirements for the admission of family members with a third-country nationality of migrated Union citizens. Grand Chamber decision of 9 January 2007, case C-1/05, "Yunying Jia v. Migrationsverket" (2007) 3(3) European Constitutional Law Rev 463-475

Peers S, 'The Court of Justice lays the foundations for the long-term residents directive: Kamberaj, Commission v. Netherlands, Mangat Singh. Case C-571/10, Servet Kamberaj v. Istituto per l'Edilizia sociale della Provincia autonoma di Bolzano (IPES) and Others, Judgment of the Court (Grand Chamber) of 24 April 2012, nyr; Case C-508/10, Commission v. Netherlands, Judgment of the Court of 26 April 2012; Case C-502/10, Staatssecretaris van Justitie v. Mangat Singh, Judgment of the Court of 18 October 2012' (2013) 50(2) CML Review 529-552 
Petrov R, Exporting the Acquis Communautaire through European Union External Agreements (Baden-Baden: Nomos, 2011)

Rennuy N, Elsuwege P, 'Integration without membership and the dynamic development of EU law: "United Kingdom v. Council (EEA)": case C-431/11, "United Kindgom v. Council (EEA)", judgment of the Court of 26 September 2013' (2014) 51(3) CML Rev 935-954

Reslow N, 'Deciding on EU external migration policy: Member States and the mobility partnerships' (2012) 34(3) Journal of European Integration 223-239

-- 'The role of third countries in EU migration policy: the mobility partnerships' (2012) 14(4) European Journal of Migration and Law 393-415

Schrauwen A, 'Granting the right to vote for the European Parliament to resident third-country nationals: civic citizenship revisited' (2013) 19(2) Eur LJ 201-218

Wiesbrock A, 'Free movement of third-country nationals in the European Union: the illusion of inclusion' (2010) 35(4) EL Review 455-475

-- Legal migration to the European Union (Leiden: M. Nijhoff 2010)

-- 'The right to family reunification of third-country nationals under EU law: Decision of 4 March 2010, Case C-578/08, Rhimou Chakroun v. Minister van Buitenlandse Zaken' (2010) 6(3) European Constitutional Law Rev 462-480

-- 'Disentangling the "Union citizenship puzzle"?: The McCarthy Case' (2011) 36(6) EL Review 861-873

-- 'Granting citizenship-related rights to third-country nationals: an alternative to the full extension of European Union citizenship?' (2012) 14(1) European Journal of Migration and Law 63-94

-- 'Sources of law, regulatory processes and enforcement mechanisms in EU migration policy: the slow decline of national sovereignty' (2013) 20(3) Maastricht Journal of European and Comparative Law 423-441 